\title{
Demersal fish predators of gelatinous zooplankton in the Northeast Pacific Ocean
}

\author{
Richard D. Brodeur ${ }^{1, *}$, Troy W. Buckley ${ }^{2}$, Geoffrey M. Lang ${ }^{2}$, Douglas L. Draper ${ }^{1}$, \\ John C. Buchanan ${ }^{1}$, Richard E. Hibpshman ${ }^{3}$ \\ ${ }^{1}$ NOAA Northwest Fisheries Science Center, Hatfield Marine Science Center, Newport, OR 97365, USA \\ ${ }^{2}$ NOAA Alaska Fisheries Science Center, Seattle, WA 98115, USA \\ ${ }^{3}$ School of Aquatic and Fishery Sciences, University of Washington, Seattle, WA 98105, USA
}

\begin{abstract}
Historically, gelatinous zooplankton have been considered important consumers or predators in marine food webs, but more recently they have also been recognized as important prey for many marine species. Here, we summarized data obtained from $>100$ Northeast Pacific fish predators based on extensive gut content analysis ( 450 000 stomachs examined) from broadscale demersal trawl surveys ranging from the Bering Sea to Southern California. In the Bering Sea, we identified 27 predators on jellyfish and 23 on urochordates. In the Aleutian Islands, 14 and 18 predators were identified, respectively, and for the Gulf of Alaska, a total of 23 and 32 such predators were documented. Off the West Coast of the contiguous USA, we identified 16 coelenterate predators and 7 urochordate predators. Many of these predators were not previously known to prey on gelatinous zooplankton. Dominant consumers of coelenterates include prowfish, rockfishes, walleye pollock, sablefish, and grenadiers, and primary consumers of urochordates included rockfishes, Atka mackerel, and sablefish. Pronounced seasonal and interannual variability in gelatinous taxa occurrence was observed in several dominant fish predators. The occurrence of jellyfish prey was generally much higher in diets of fishes examined fresh at sea when compared with diets of the same species examined in the laboratory following preservation. Differences in occurrence were less pronounced with the more durable urochordate prey. We suggest that many existing estimates of predation on easily dissolved gelatinous prey may underestimate the true predation rate and the importance of these organisms in marine food webs.
\end{abstract}

KEY WORDS: Jellyfish $\cdot$ Cnidarians $\cdot$ Thaliaceans $\cdot$ Nekton $\cdot$ Diets $\cdot$ Demersal fish $\cdot$ Digestion rate

\section{INTRODUCTION}

Gelatinous zooplankton are conspicuous and often extremely abundant components of many coastal ecosystems (Richardson et al. 2009, Brotz et al. 2012, Condon et al. 2013). They are known to impact plankton and fish populations in many ecosystems due to their high consumption rates. They may also affect fish populations through direct predation on early life stages or via competition with juveniles and adults (Arai 1988, Purcell \& Arai 2001, Opdal et al. 2019). Although some large-scale surveys (Mianzan

\footnotetext{
${ }^{*}$ Corresponding author: ricbrodeur1@gmail.com
}

et al. 1996, Diaz Briz et al. 2017, 2018) or literature reviews (Kashkina 1986, Purcell \& Arai 2001, Arai 2005, Ates 2017) have shown gelatinous taxa to be important to many different predators, documentation of fish feeding on gelatinous zooplankton has been limited for most marine ecosystems. In a search of the extensive FishBase online database, Pauly et al. (2009) found only 124 species known to consume jellyfish, of which 11 are primarily gelatinous feeders. As a result, gelatinous zooplankton are often ignored or considered trophic 'dead ends' in many ecosystem models (Pauly et al. 2009).

() R. E. Hibpshman and outside the USA The U.S. Government 2021. Open Access under Creative Commons by Attribution Licence. Use, distribution and reproduction are unrestricted. Authors and original publication must be credited.

Publisher: Inter-Research · www.int-res.com 
The Northeast Pacific Ocean is a diverse and highly productive region encompassing several Large Marine Ecosystems (LMEs) that contribute heavily to the world's fisheries catch. This region is very dynamic, and is presently undergoing dramatic changes in ecosystem functions and production. Of particular relevance is the recent increase in gelatinous zooplankton in several Northeast Pacific LMEs, related to both natural and human-induced perturbations to the ecosystem (Brodeur et al. 2008, 2017, Brotz et al. 2012, Li et al. 2016, Uye \& Brodeur 2017). These increases may come at the expense of production of many of their competitors (e.g. krill and forage fishes), leading to very different food webs than would occur in the absence of these blooms (Ruzicka et al. 2012, 2020, Opdal et al. 2019). Although some noteworthy, mostly pelagic, predators such as chum salmon Onchorhychus keta (Brodeur et al. 2007), sablefish Anoplopoma fimbria (Laidig et al. 1997), widow Sebastes entomelas (Adams 1987, Lee \& Sampson 2009) and blue $S$. mystinus rockfish (Hobson et al. 1996, Hobson \& Chess 1988), and forage fishes (Brodeur et al. 2019a) are known to consume various forms of gelatinous zooplankton in marine waters of the Northeast Pacific Ocean, we lack a general understanding of the overall importance of gelatinous prey to the demersal food webs in these waters. Studies of demersal fishes in other oceans indicate that some taxa may be important consumers but they are often overlooked as predators on gelatinous zooplankton (Arkhipkin \& Laptikhovsky 2013, Smith et al. 2016).

To evaluate the importance of gelatinous zooplankton in the diets of juvenile and adult fishes along the west coast of North America, we synthesized fish and elasmobranch diet data from previously published studies or, when available, from unpublished data sets and analyzed multiple species in several geographical areas. Although there are examples of studies from this region that found gelatinous zooplankton to be important for individual predators, our aim was to examine multispecies diet surveys from a broad array of demersal fishes and elasmobranchs for frequency of occurrences (or percent by weight when available) of gelatinous prey, and to examine, where possible, interannual, geographic, and spatial variation in the consumption of major gelatinous prey organisms. We also examined 2 different stomach sampling methodologies to evaluate potential biases in the detection of gelatinous prey resulting from stomach sample identification in a shore laboratory following preser- vation, as opposed to identification at sea using freshly caught specimens.

\section{MATERIALS AND METHODS}

\subsection{Sampling programs}

Starting in 1981, systematic collections have been made of groundfish stomachs as part of the Resource Ecology and Ecosystem Modeling Task at the Alaska Fisheries Science Center (AFSC) and described in more detail in Livingston et al. (2017) (data available from www.afsc.noaa.gov/REFM/ REEM/Data/Default.htm). Quantifying food web linkages is essential to increase our understanding of how external forces such as fishing and climate change may cause unanticipated shifts in ecosystem composition. Stomach samples were primarily collected from trawl-caught groundfish by NOAA scientists aboard research surveys during the summer (mainly from the middle of May to the end of August). In order to sample at other times of the year, collections from commercial bottom (and some midwater) trawls were made by Fishery Observers from the same regions sampled by the surveys but from months outside of AFSC survey periods. Stomach samples that were preserved in the field and returned to the lab for processing and data collection account for the majority of our database. A smaller number of stomach samples $(<1 \%)$ were analyzed at sea in as quantitative a manner as possible by trained stomach analysts. Geographic coverage of the data was categorized into 4 broad regions: Bering Sea, Gulf of Alaska, Aleutian Islands, and West Coast (Fig. 1a). For the latter region, including California, Oregon, and Washington, sampling by the AFSC occurred only up to 1992 (Buckley et al. 1999).

Starting in 2005, stomach collections from the West Coast Groundfish Bottom Trawl Survey conducted by the Northwest Fisheries Science Center (NWFSC), US National Marine Fisheries Service (Keller et al. 2017) were examined to document food web interactions of a subset of key species. This survey is a depth stratified, random sampling program that covers approximately the area from the US-Mexico border $\left(32^{\circ} 30^{\prime} \mathrm{N}\right)$ north to Cape Flattery, WA $\left(48^{\circ} 10^{\prime} \mathrm{N}\right)$ and covers a depth range of 55-1280 m (Fig. 1b). This summer survey is conducted annually from mid-May through July and late August through October. Up to 5 samples tow ${ }^{-1}$ were randomly collected from non-embolized fish. 


\subsection{Synthesis of fish diet studies in the Northeast Pacific Ocean}

Identification of specific taxa in predator stomachs is subject to inherent biases not present in analysis of plankton or benthic samples. Prey may only partially be consumed by the predator or damaged in the ingestion and assimilation process. In particular, gelatinous prey are quickly digested in the stomachs of fish predators compared to hard-bodied prey (Arai et al. 2003); therefore, they often can only be identified at broad taxonomic categories (Cnidaria, Ctenophora, Thaliacea, and Appendicularia). The collective noun, gelatinous zooplankton, encompasses many diverse and often unrelated taxa, with varying life histories and functional relationships (Lucas \& Dawson 2014). In our study we found it necessary to combine some taxa with similar body forms due to the difficulty in differentiating them in stomach samples by even the most experience stomach analyst. The softer bodied predatory forms including the Phyla Cnidaria and
Ctenophora were combined into a coelenterate group called 'jellyfish' by Lucas \& Dawson (2014), as well as in the present study, and the more rigid bodied, filter-feeding pelagic thaliaceans and appendicularians were combined as urochordates in our analyses, even if they were able to be identified to genera or species in the original study. We summarized utilization of these 2 gelatinous groups using both frequency of occurrence and gravimetric contribution for each predator species. We also highlight which species were examined with some intensity but were not found to prey on gelatinous organisms to any appreciable degree. In this study, we define a gelativore as a taxon which had $>25 \%$ by weight of either group of gelatinous zooplankton in its diet.

\subsection{Data collection and analysis}

For the stomach contents data from Alaskan waters, we used 2 different methods of processing

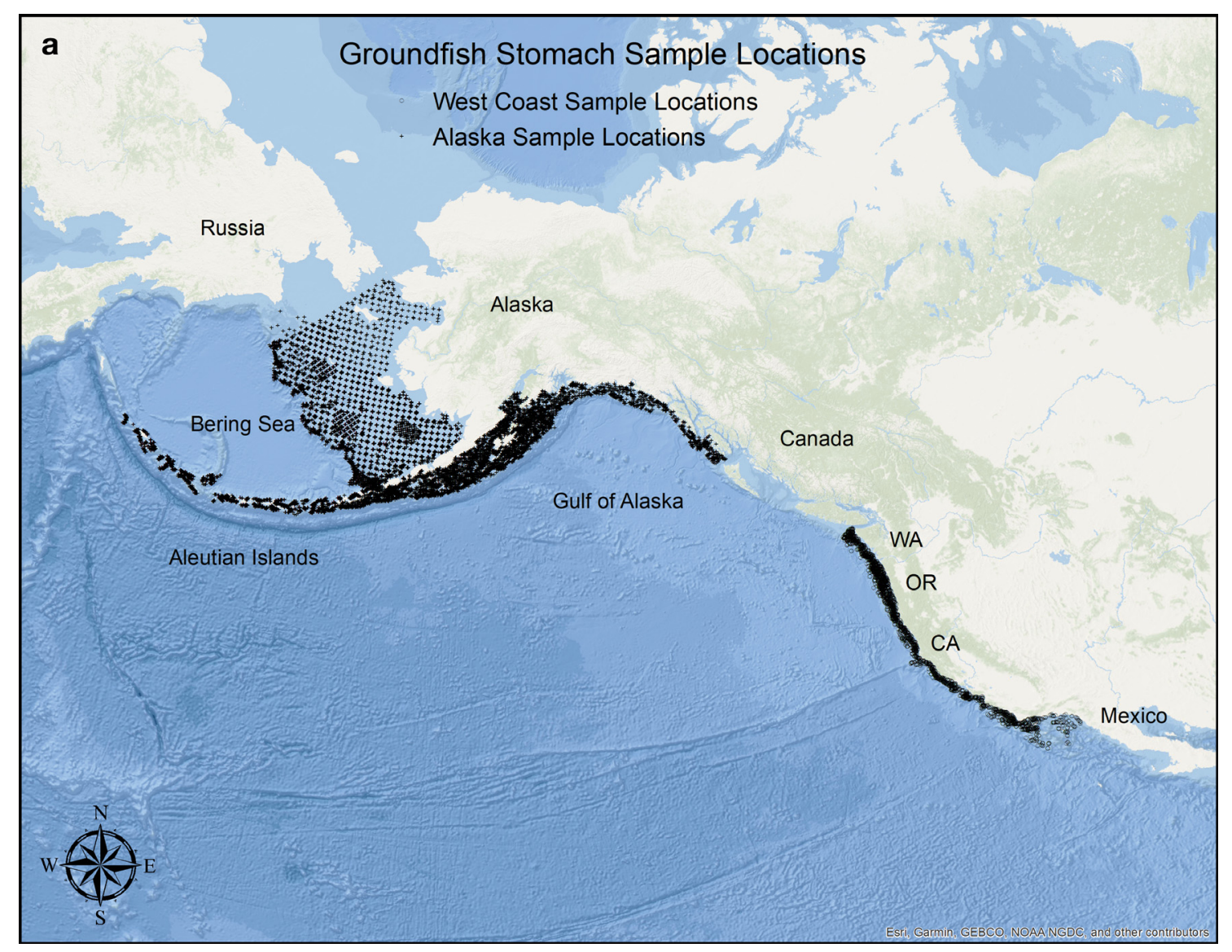

Fig. 1. (Continued on next page). Bottom trawl sampling intensity and geographic regions where diet data of fish were examined and included in this study. Locations of (a) Alaska Fisheries Science Center (AFSC) stomach collections (WA: Washington; OR: Oregon; CA: California); and (b) Northwest Fisheries Science Center (NWFSC) collections 

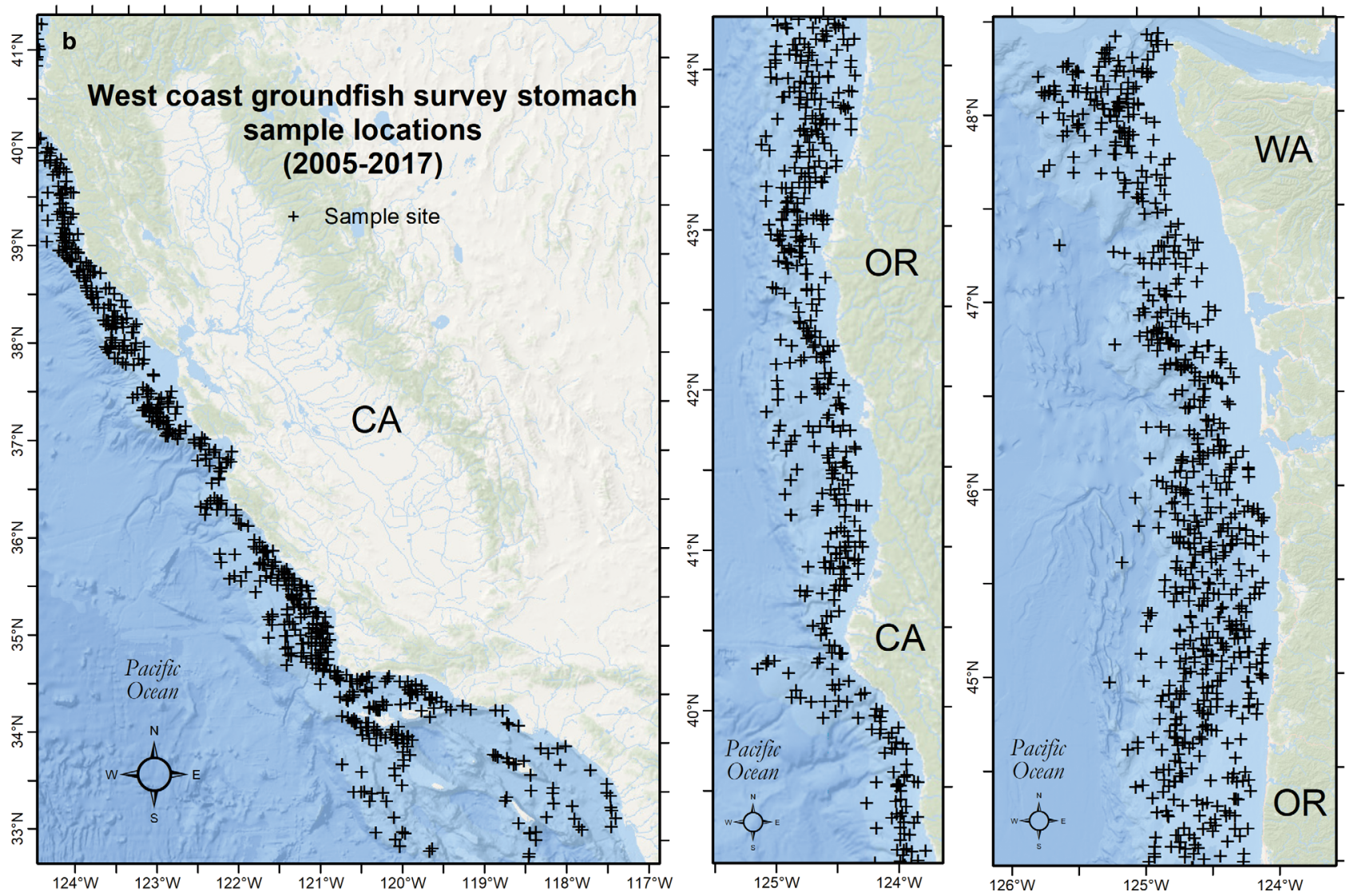

Fig. 1 (continued).

and data collection on the same species within the same time period and region in several instances. The first involved processing and analyzing stomachs at sea as fish first arrive on deck in a process called Stomach Content ANalysis at Sea (SCANS). Because of limited resources, equipment, and time for fish stomach analysis at sea, SCANS were conducted by stomach analysts with extensive experience identifying fish and invertebrate prey found in each region. In the SCANS method, stomach contents were identified to the lowest practical taxonomic level and weighed to the nearest $0.5 \mathrm{~g}$. The other method involves stomachs excised at sea and processed by initially fixing them in buffered $10 \%$ formalin. Upon returning the samples to the laboratory, the formalin was neutralized, the samples rinsed with water, and then stored in $70 \%$ ethanol. The stomach contents were removed and examined with a dissecting microscope. Prey items were sorted and identified to the lowest practical taxonomic level, blotted dry, and then weighed to the nearest $0.01 \mathrm{~g}$. For both methods, the percentage of total prey weight for each taxon, as well as the percentage of stomachs containing each taxon, was calculated for each spe- cies. The NWFSC stomach collections were preserved at sea and analyzed in the laboratory. The stomachs were excised, placed into individual cloth bags, and preserved in $10 \%$ buffered formalin at sea. The stomach samples were subsequently rinsed in water and stored in $70 \%$ ethanol when returned to the laboratory at the conclusion of the survey. In the laboratory, stomach contents were identified, blotted dry, and individual taxa were weighed to the nearest $0.01 \mathrm{~g}$ damp weight.

Our sampling methods differ somewhat due to constraints imposed by time, conditions, equipment, and references available to the analyst. Prior analysis indicated that comparisons of the data from these differing methods produce differences in the ability to detect and identify some prey types including some soft-bodied prey (R. E. Hibpshman unpub. data). Pairwise comparisons were made between the frequency of detection using SCANS and laboratory analysis of the 2 main prey groups considered herein, jellyfish (cnidarians and ctenophores) and urochordates (thaliaceans or larvaceans), for each predator/region/year. Empty stomachs were excluded from the analyses. For these binomial (presence/absence) data, Fisher's 
exact test was used when total sample size (laboratory + SCANS) was $<31$ (preferred analysis when cell frequencies are small) and the $2 \times 2$ contingency test with Cochran's correction for continuity was used when total sample size was $>30$ (Zar 1984).

\section{RESULTS}

We summarized diet information from 455969 stomach samples comprising more than 100 demersal teleosts and elasmobranchs (Table 1). In the Bering Sea, we identified 28 predators on jellyfish and 23 predators on urochordates (Table 1). Many species exhibited low percent weight of gelatinous taxa, but 7 species had $>3 \%$ of their diet by weight consisting of jellyfish along with 7 taxa showing similar weight percentages of urochordates (Table S1 in the Supplement at www.int-res.com/articles/suppl/m658p089_ supp.pdf). Dominant gelativores were the smooth lumpsucker Aptocyclus ventricosa and prowfish $\mathrm{Za}$ prora silenus, but these species were not examined in great numbers due to their rarity in the catches. However, sablefish, walleye pollock Gadus chalcogrammus, and Atka mackerel Pleurogrammus monopterygius had $>1 \%$ weight percentages, and are all commercially exploited species (Table S1). In the Aleutian Islands, 14 and 18 predators were identified on the 2 gelatinous zooplankton groups (Table 1) with a similar species composition as that observed in the Bering Sea and the addition of several rockfish species (Table S2). Four predators had $>3 \%$ by weight of jellyfishes and 6 had similar percentages of urochordates. Prowfish was the dominant gelativore in the Aleutian Island area but dark rockfish Sebastes ciliatus, dusky rockfish S. variabilis, and sablefish were also important (Table S2). A total of 24 and 32 gelatinous predators on the 2 groups were found in the Gulf of Alaska (Table 1), with many of the same dominant species as in the Bering Sea and Aleutian Islands (Table S3). Seven species of jellyfish predators and 9 species of urochordate predators ( $>3 \%$ by weight) were identified. Additional species of gelativorous predators not found in the previous regions include the searcher Bathymaster signatus, barreleye Macorpinna microstoma, California headlightfish Diaphus theta, and the bluethroated argentine Nansenia candida, but these predators are mainly midwater or deep-sea species of little commercial importance (Table S3).

The number of gelatinous zooplankton predators along the West Coast varied between AFSC and NWFSC surveys. Of the 14 predators examined from AFSC West Coast trawl surveys, 4 consumed coelenterates and 2 urochordates (Table 1). None of these exceeded the $3 \%$ threshold of gelatinous consumption (Table S4). The more recent NWFSC West Coast collections showed much higher incidences of predation on both coelenterates (15 species) and urochordates (6 species) than the previous survey (Table 1), which may be due to the greater number of taxa with sufficient sample sizes in the later period. Dominant (>3\% by weight) consumers of coelenterates in this survey included darkblotched $S$. crameri, yellowtail $S$. flavidus, and widow rockfish, and dominant consumers of urochordates included sablefish, Pacific sanddabs Citharichthys sordidus, and widow rockfish (Table S5). None of the taxa in either West Coast survey were considered to be major gelativores (i.e. $>25 \%$ by weight of the dietary items).

Based on frequency of gelatinous prey in stomachs, prowfish and sablefish had the highest occurrence (both $>0.5$ ) of coelenterates whereas gadids (walleye pollock and Arctic cod Boreogadus saida) and giant grenadier had the highest occurrence of urochordates in the Bering Sea (Fig. 2a). In the Aleutian Islands region, prowfish and dark rockfish had the highest incidence of coelenterates, and prowfish, dusky rockfish, and Atka mackerel had high incidences of urochordates (Fig. 2b). Coelenterates were found in all the prowfish stomachs examined in the Gulf of Alaska region, but only

Table 1. Years of collections, total number of species examined, total number of stomachs examined, and number and percentage of taxa containing jellyfish and urochordates by geographic area (Region). The total number of stomachs only includes species with $>10$ stomachs containing identifiable prey items

\begin{tabular}{|c|c|c|c|c|c|c|c|}
\hline \multirow[t]{2}{*}{ Region } & \multirow[t]{2}{*}{ Years } & \multirow{2}{*}{$\begin{array}{l}\text { No. of species } \\
\text { examined }\end{array}$} & \multirow{2}{*}{$\begin{array}{l}\text { No. of stomachs } \\
\text { examined }\end{array}$} & \multicolumn{2}{|c|}{ Containing jellyfish } & \multicolumn{2}{|c|}{ Containing urochordates } \\
\hline & & & & $\mathrm{n}$ & $\%$ & $\mathrm{n}$ & $\%$ \\
\hline Bering Sea & 1981-2017 & 92 & 312805 & 28 & 30.43 & 23 & 25.00 \\
\hline Aleutian Islands & $1981-2012$ & 34 & 37088 & 14 & 41.18 & 18 & 52.94 \\
\hline Gulf of Alaska & 1981-2017 & 72 & 84588 & 24 & 33.33 & 32 & 44.44 \\
\hline West Coast & 1980-1992 & 14 & 16368 & 4 & 28.57 & 2 & 14.29 \\
\hline West Coast & 2005-2017 & 22 & 5120 & 15 & 68.18 & 6 & 27.27 \\
\hline
\end{tabular}



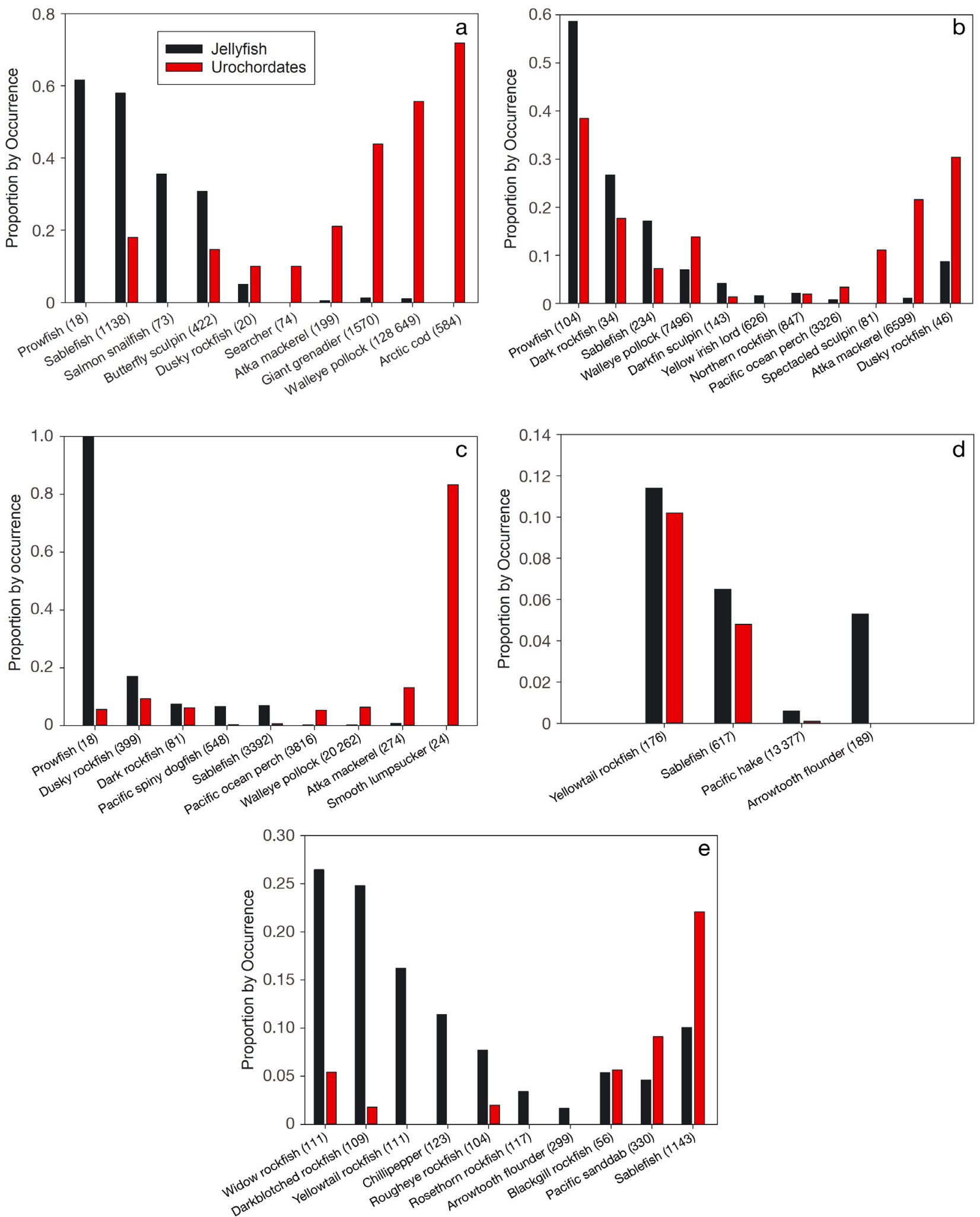

Fig. 2. Proportional occurrence of jellyfish and urochordates in diets of several important fishes in NMFS bottom trawl surveys in the (a) Bering Sea, (b) Aleutian Islands, (c) Gulf of Alaska, (d) AFSC west coast, and (e) NWFSC west coast for all years combined. Sample size for each predator is shown in parentheses. See the Supplement (www.int-res.com/articles/suppl/m658 p089_supp.pdf) for scientific names 
smooth lumpsucker diets showed a preponderance of urochordates (Fig. 2c). Both prey groups were relatively less important in the 1980-1992 West Coast regions and only yellowtail rockfish had $>0.1$ proportions for either of these prey groups (Fig. 2d). The more recent data (2005-2017) showed high incidences of coelenterates in widow and darkblotched rockfish and higher occurrences of urochordates only in sablefish (Fig. 2e).

We found that there were a number of species that did not consume gelatinous prey in appreciable proportions in all the geographic areas examined. For the Bering Sea, some of the more notable nongelativorous species included Pacific cod Gadus macrocephalus, arrowtooth flounder Atheresthes stomias, Pacific halibut Hippoglossus stenolepis, Greenland turbot Reinhardtius hippoglossoides, and Alaska skate Bathyraja parmifera, all of which had $>1500$ stomachs examined (Table S1). Similarly, for the Aleutian Islands region, arrowtooth flounder, Pacific halibut, and Kamchatka flounder Atheresthes evermanni were intensely examined but lacked appreciable proportions of gelatinous prey (Table S2). For the Gulf of Alaska, Pacific cod, arrowtooth flounder, and Pacific halibut were joined by flathead sole Hippoglossoides elassodon, rougheye rockfish $S$. aleutianus, and shortspine thornyhead Sebastolobus alascanus (Table S3). For the West Coast surveys, notable non-gelativores included Pacific hake Merluccius productus, Dover sole Microstomus pacificus, arrowtooth flounder, lingcod Ophiodon elongatus, shortspine and longspine Sebastolobus altivelis thornyhead, petrale sole Eopsetta jordani, and Pacific ocean perch (Tables S4 \& S5).

The spatial distribution of urochordate occurrences for all groundfish predators combined was examined for the northern 3 regions sampled among some contrasting years of high (2004 and 2013) and low (2009 and 2015) occurrence (Fig. 3). The spatial distribution of hotspots of predation on urochordates varied by year but appeared to be concentrated near canyons along the outer shelf of the Bering Sea and in deep passages between the Aleutian Islands (Fig. 3). Along the west coast, there was only one confirmed occurrence of urochordate predation from 2005-2014 (from a widow rockfish) despite extensive sampling (Fig. 4). Urochordates, of which $>99 \%$ were pyrosomes, became prevalent starting in 2015 and increased in intensity in the diets of demersal fishes the following $2 \mathrm{yr}$ along the entire coast (Fig. 4).

In the northern regions, consistent sampling has occurred since the 1980s, and we examined interannual and seasonal variability for some dominant species with adequate sample size (i.e. minimum number of stomachs of at least 60 for any species/ year or species/month combination). Walleye pollock showed substantial interannual variability in consumption of urochordates in all 3 regions examined, but the peak occurrences did not align among the regions (Fig. 5). There was a slight increase in occurrence of both jellyfish and urochordates through the sampling period. Atka mackerel had relatively stable occurrences of urochordates over the last $30 \mathrm{yr}$ of sampling (Fig. 5). Gulf of Alaska sablefish fed at a higher frequency on jellyfish than urochordates. The frequency of occurrence of jellyfish in sablefish diet varied considerably throughout the sampling period, whereas consumption of urochordates increased during the latter portion of the time series (Fig. 5). The monthly feeding occurrence of urochordates showed substantial seasonality for walleye pollock, although the month of peak occurrence shifted from May in the Gulf of Alaska, to June in the Aleutian Islands, to July in the Bering Sea (Fig. 6). Aleutian Island Atka mackerel and Gulf of Alaska sablefish showed similar patterns, although the latter consumed low amounts of urochordates (Fig. 6). Jellyfish showed little seasonality in their occurrence for walleye pollock and Atka mackerel, but sablefish had higher occurrences in spring and fall, with a decline in summer (Fig. 6).

The SCANS methodology detected significantly higher occurrences of jellyfish in the diet of sablefish (2007 and 2009) and significantly lower urochordates in the diet of walleye pollock (2009 only) in the Gulf of Alaska (Table 2). Other significant differences for which the sample sizes are much lower included prowfish, dusky rockfish, and dark rockfish from the Aleutian Islands and Atka mackerel from the Gulf of Alaska (Table 2). Specimens of jellyfish removed from predator stomachs and then preserved were completely dissolved when re-examined in the laboratory (authors' pers. obs.); urochordates appear to preserve relatively well by comparison (Table 2 ).

\section{DISCUSSION}

In an extensive survey ranging over much of the western coast of North America from subarctic to subtropical ecosystems, we identified numerous demersal fish and elasmobranch predators of both jellyfish and urochordates, some of which had never previously been identified as predators of gelatinous zooplankton. Among the dominant gelatinous predators we observed were walleye pollock, sablefish, 

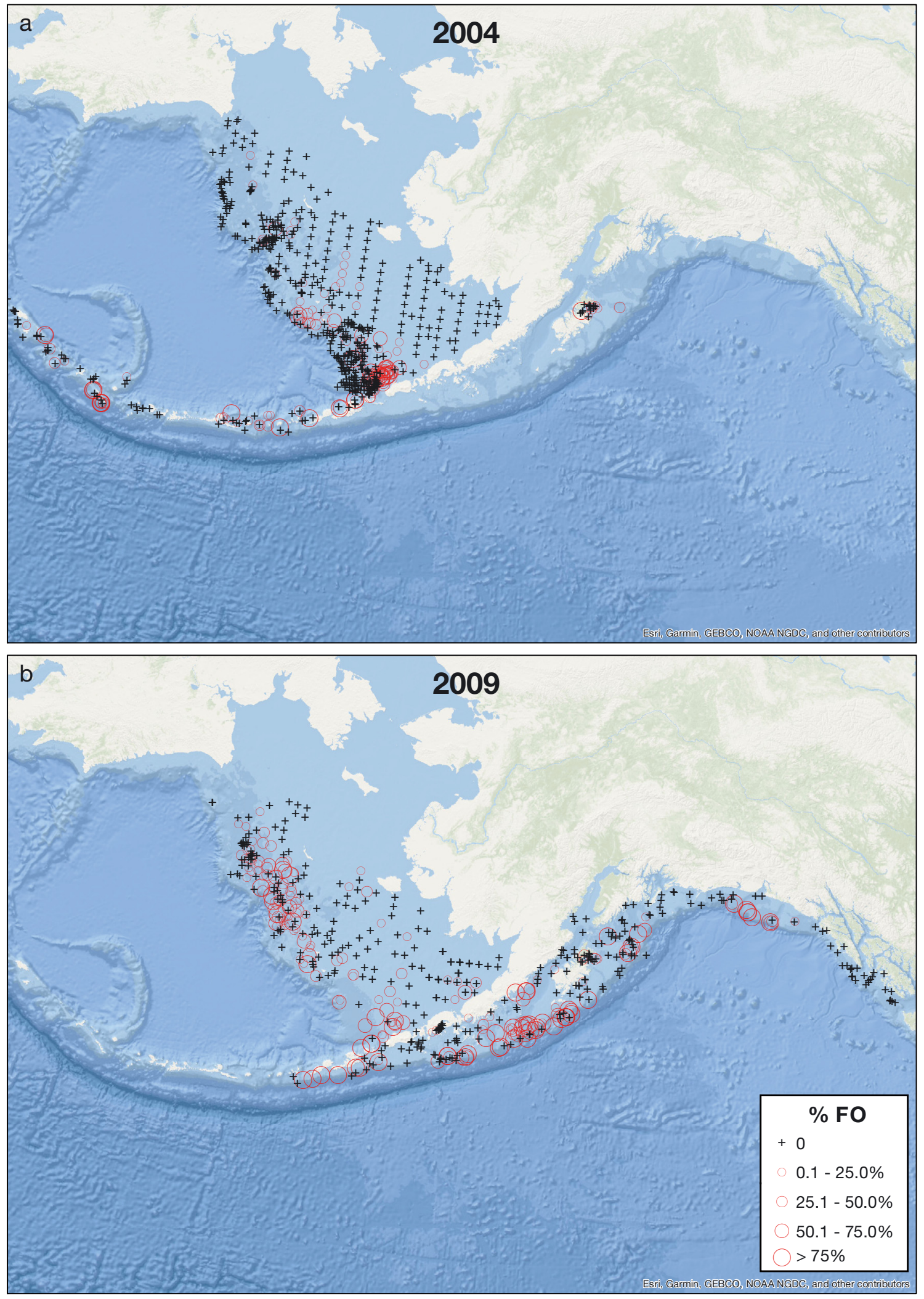

Fig. 3. (Continued on next page). Haul-specific percent frequency of occurrence (\%FO) of urochordates in the combined diets of demersal fishes from the Bering Sea, Aleutian Islands, and Gulf of Alaska from bottom trawl surveys during (a) 2004, (b) 2009, (c) 2013, and (d) 2015 

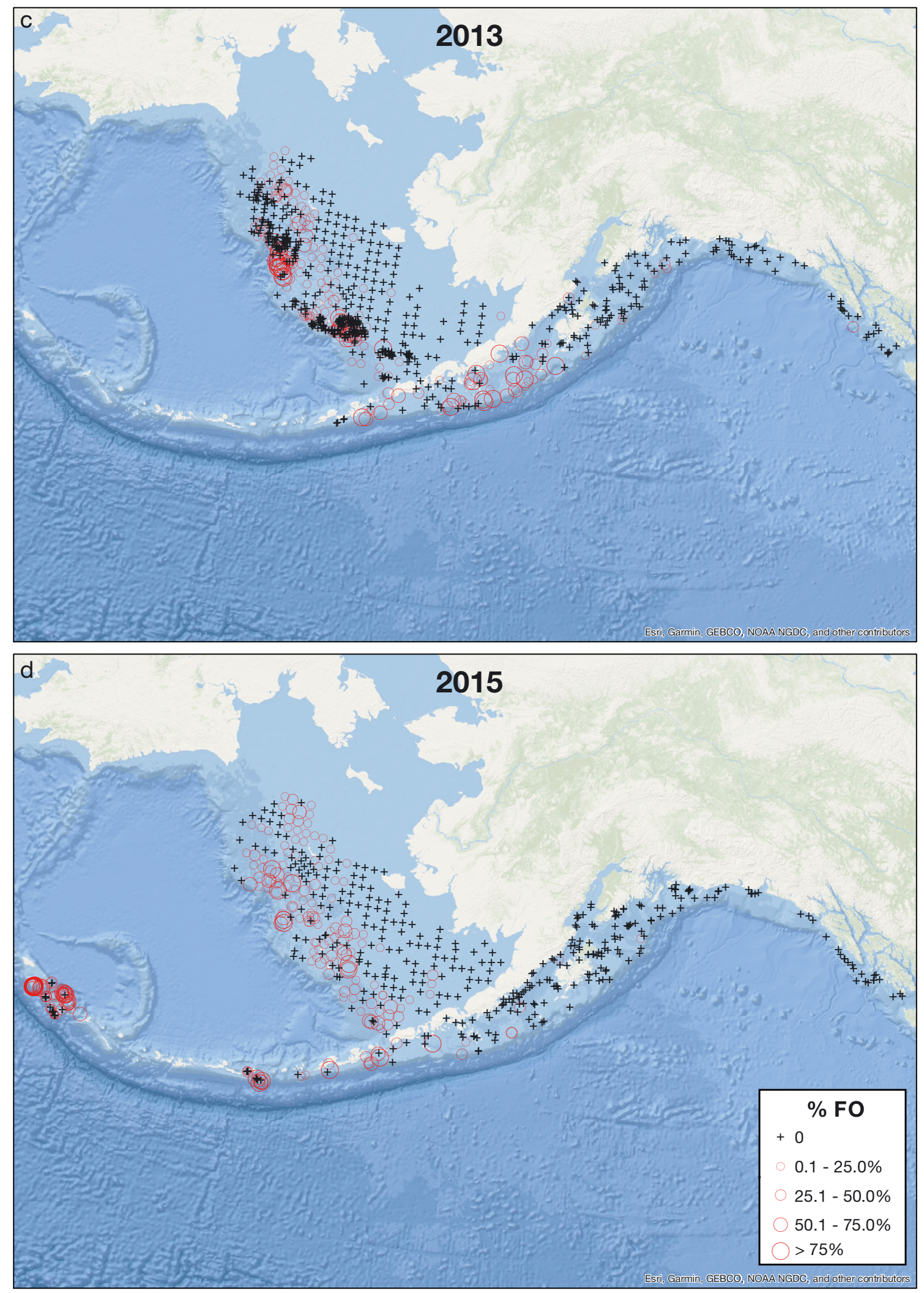

Fig. 3. (Continued) 


\section{a 2004-2015}

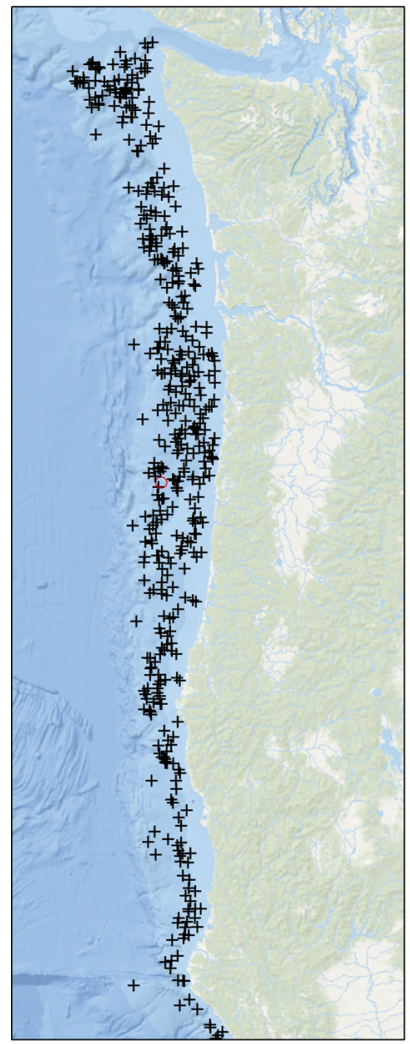

b 2004-2015
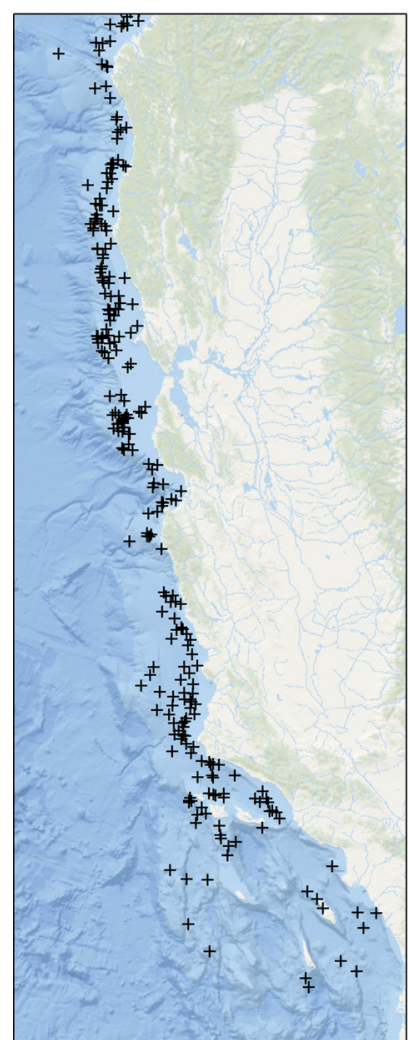

2015

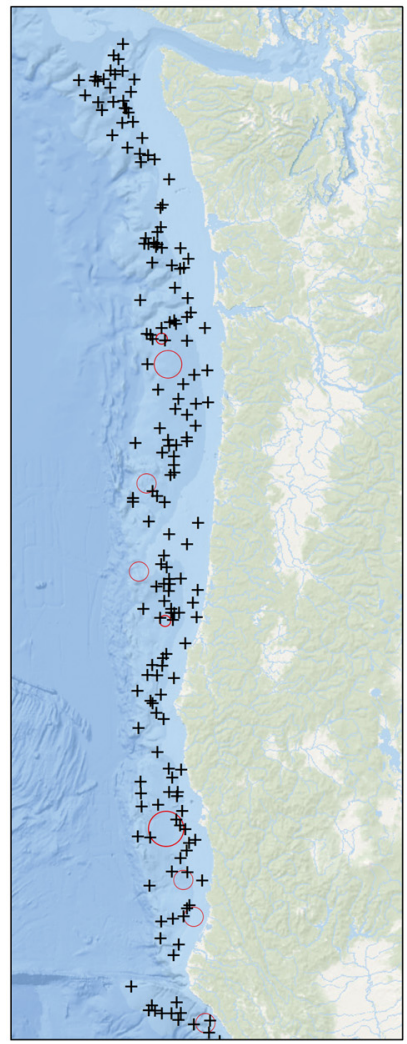

2015

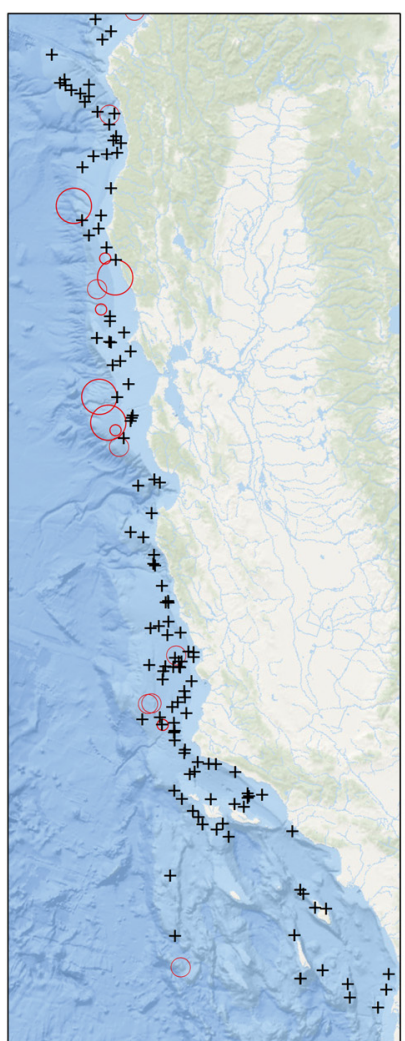

2016

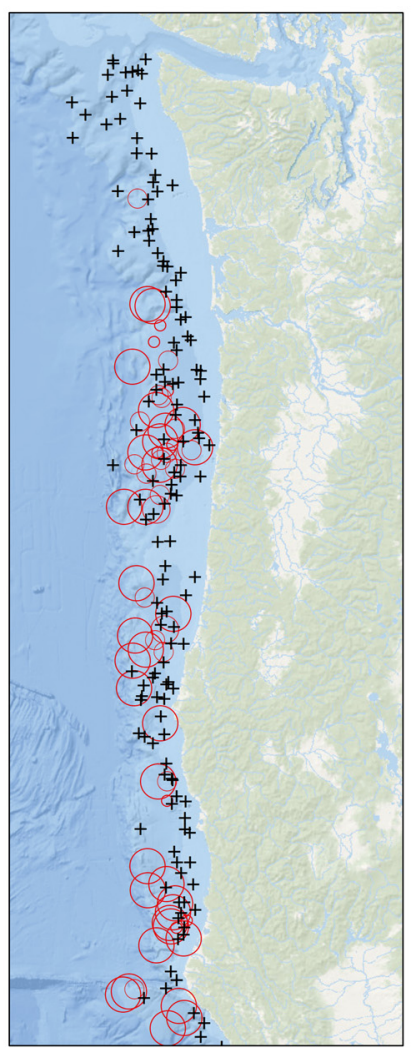

2016

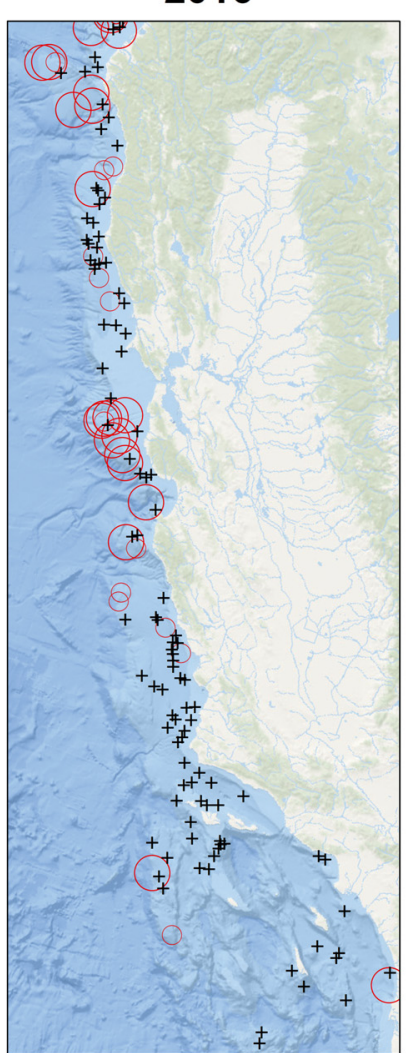

2017

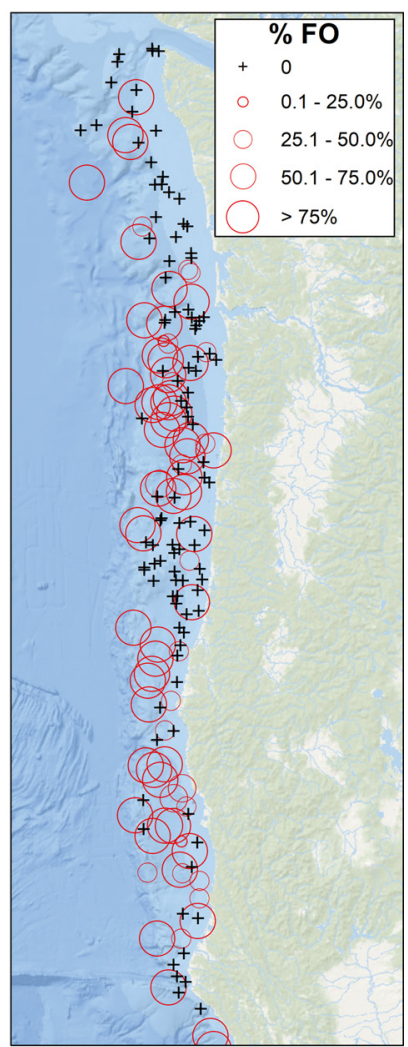

2017

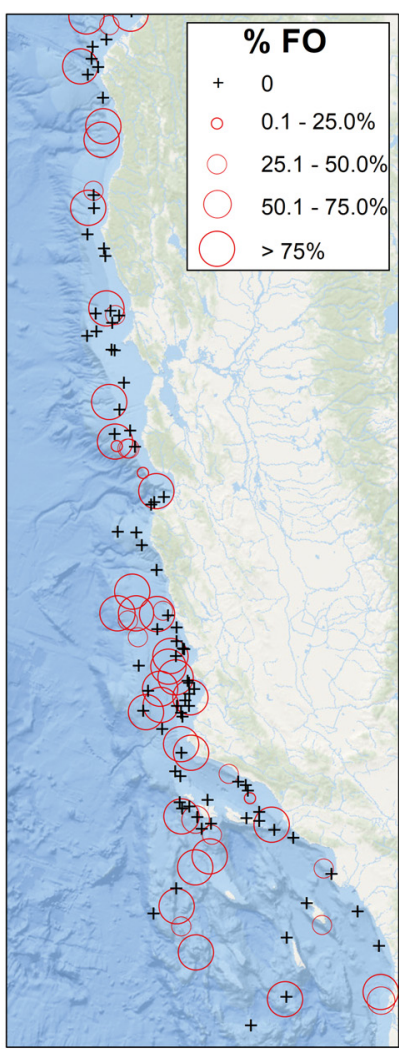

Fig. 4. Haul-specific percent frequency of occurrence (\%FO) of urochordates in the combined diets of demersal fishes from (a) the Northern and (b) the Southern regions of the West Coast bottom trawl surveys during 2005-2014, 2015, 2016, and 2017 

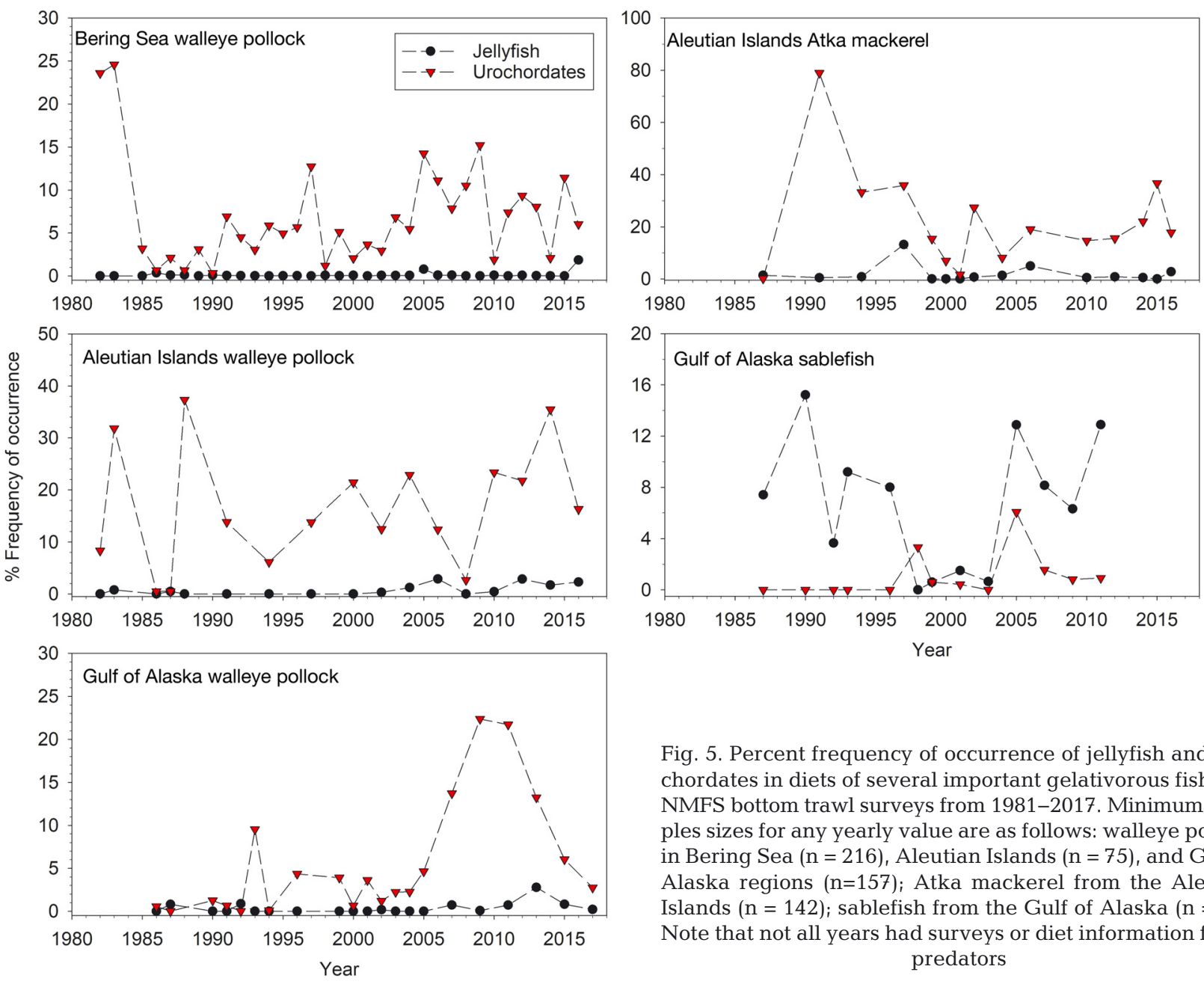

Atka mackerel, prowfish, along with many different rockfish species. We also noted many species that did not appear to utilize gelatinous zooplankton as prey in any sizable amount in all regions examined. These included many larger flatfishes that feed mostly on large pelagic prey such as Pacific halibut, arrowtooth, and Kamchatka flounder, several microcarnivorous flatfishes (Dover, flathead and petrale sole), Pacific cod and hake, and both shortspine and longspine thornyhead.

The interannual variation we observed in the occurrence of gelatinous prey showed somewhat different patterns for the different LMEs for walleye pollock, the species with one of the highest biomasses (and sampling frequency) in the northern regions (Fig. 5). Although jellyfish were not commonly consumed by walleye pollock among the 3 examined Alaskan regions $(0.03,0.33$, and $0.032 \%$ for the Bering Sea, Aleutian Islands, and Gulf of Alaska respectively), urochordate predation varied in a somewhat cyclical pattern for all 3 regions, although

Fig. 5. Percent frequency of occurrence of jellyfish and urochordates in diets of several important gelativorous fishes in NMFS bottom trawl surveys from 1981-2017. Minimum samples sizes for any yearly value are as follows: walleye pollock in Bering Sea $(n=216)$, Aleutian Islands $(n=75)$, and Gulf of Alaska regions $(\mathrm{n}=157)$; Atka mackerel from the Aleutian Islands $(\mathrm{n}=142)$; sablefish from the Gulf of Alaska $(\mathrm{n}=60)$. Note that not all years had surveys or diet information for all predators

the years of high abundance did not coincide among regions (Fig. 5). Unfortunately, we do not have long time series of the abundance of all jellyfishes in these regions, but the Bering Sea pattern that was observed from walleye pollock diets is reminiscent of that found by Brodeur et al. (2008) for scyphomedusae in the same area. A large increase in urochordate predation by Gulf of Alaska walleye pollock began in 2007, which occurred somewhat before the documented increase in salp abundance that started in 2011 (Li et al. 2016). These authors attributed this increase in salp abundance and biomass throughout the Gulf of Alaska to anomalous northward transport that moved these generally offshore populations on to the shelf. There are few time series of jellyfish available for the Gulf of Alaska, but the jellyfish bycatch from the bottom trawl survey from which the fish stomachs (Fig. 4.4.4 in Uye \& Brodeur 2017) were collected exhibited high catches in 1990 and 2005, similar to the sablefish patterns but very low catches in 2011, another peak year of consumption (Fig. 5). 

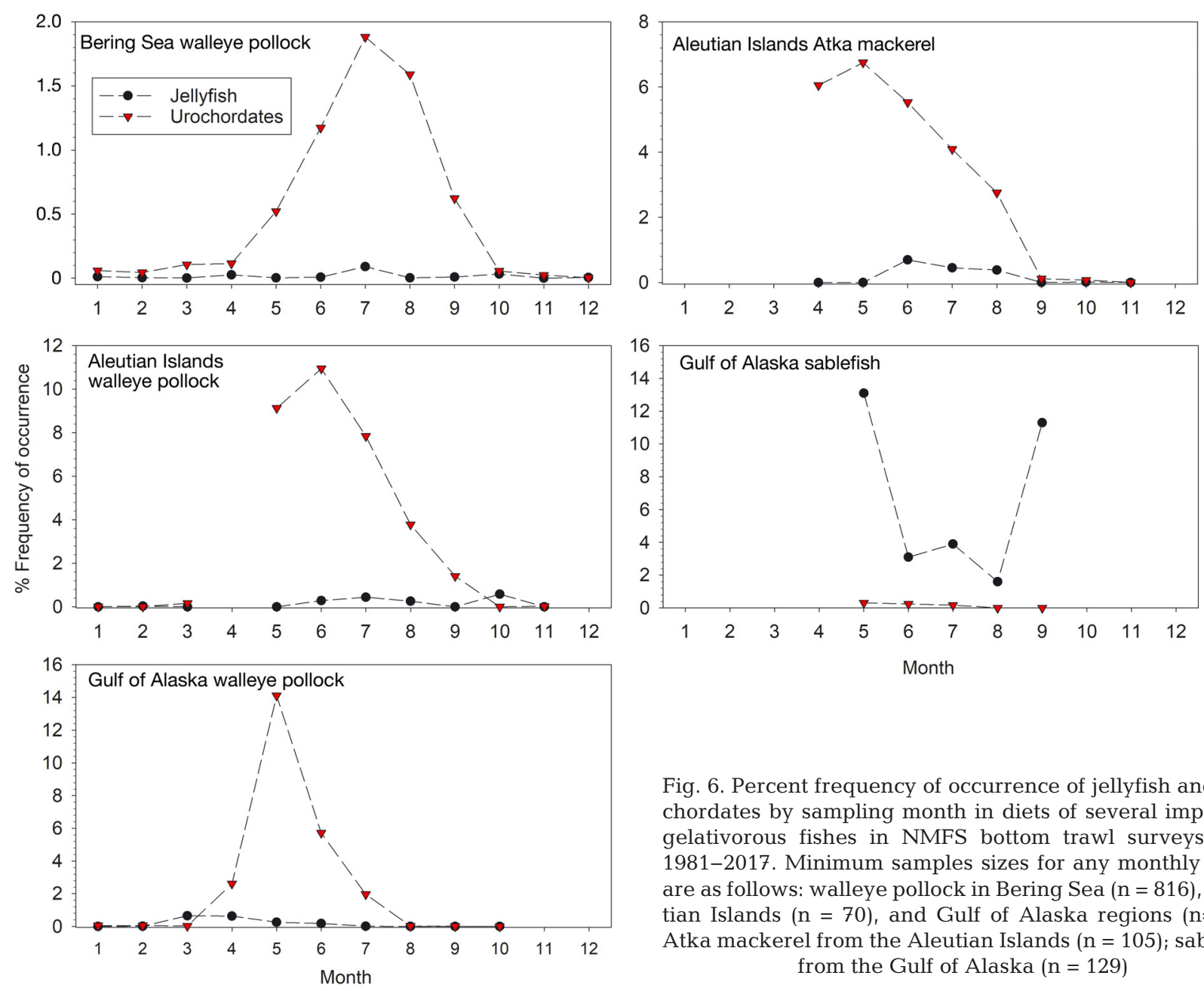

Off the west coast, increases in gelatinous zooplankton in both plankton tows and predator stomachs are likely the result of anomalous transport due to an El Niño event or reduced upwelling (Brodeur \& Pearcy 1992, Brodeur et al. 2019a). Because of difficulties in identifying specific gelatinous groups at advanced digestion stages, we may lose some information about finer scale spatiotemporal patterns. However, particularly for the West Coast, almost all identified thaliacians since 2014 were the pelagic colonial pryrosome Pyrosoma atlanticum, which may be more resistant than other gelatinous zooplankton to digestion due to its rigid tunic. This species normally has a more subtropical distribution, and only infrequently occurs in the Southern California Current, but has occurred in extremely high abundances in plankton and trawl collections throughout the West Coast since the onset of an extended marine heatwave, which started in 2014 (Brodeur et al. 2017, 2019b) and was particularly abundant in 2016 and 2017 (Miller et al. 2019). These pelagic tunicates ap-

peared in very high incidences in the diets of several pelagic predators (pelagic rockfishes and salmon) but also in a number of demersal species including sablefish and some flatfishes that tended to feed primarily on near-bottom prey. These latter occurrences may have been due to utilization of recently dead pyrosomes that sunk to the bottom where they could be consumed by many demersal invertebrate and vertebrate predators (Brodeur et al. 2017, Archer et al. 2018). P. atlanticum was also reported from the Gulf of Alaska in 2017 but in much reduced biomasses (Brodeur et al. 2017). Only 3 occurrences of this pyrosome were noted among sampled fishes from the Gulf of Alaska, all in 2017, and none were observed in stomachs collected from the Bering Sea or Aleutian Island area (G. M. Lang unpub. data). The anomalous warm and generally unproductive conditions associated with the 2015-2017 marine heatwave likely shifted the dominant food sources available to predators (Brodeur et al. 2019b), and resulted in many species, including forage fish spe- 
Table 2. Percent frequency of occurrence (\%FO) of jellyfish and urochordate prey in the diets of groundfishes in the Aleutian Islands (AI) and Gulf of Alaska (GOA) based on laboratory (Lab) or at-sea (SCANS) analyses. Pair-wise comparisons indicate significant differences by method for some predator/region/years $\left({ }^{*} \mathrm{p}<0.05,{ }^{* *} \mathrm{p}<0.01,{ }^{* * *} \mathrm{p}<0.001\right)$

\begin{tabular}{|c|c|c|c|c|c|c|c|c|}
\hline \multirow[t]{2}{*}{ Predator } & \multirow[t]{2}{*}{ Year } & \multirow[t]{2}{*}{ Region } & \multicolumn{2}{|c|}{ Sample size } & \multicolumn{2}{|c|}{ Jellyfish \%FO } & \multicolumn{2}{|c|}{ Urochordates \%FO } \\
\hline & & & Lab & SCANS & Lab & SCANS & Lab & SCANS \\
\hline Dark rockfish & 2010 & $\mathrm{AI}$ & 10 & 8 & 0.0 & $52.9^{*}$ & 0.0 & 17.6 \\
\hline Dusky rockfish & 2010 & $\mathrm{AI}$ & 8 & 4 & 0.0 & $100.0^{*}$ & 12.5 & 0.0 \\
\hline Prowfish & 2010 & AI & 2 & 18 & 0.0 & $100.0^{*}$ & 0.0 & 5.6 \\
\hline Sablefish & 2007 & GOA & 113 & 119 & 4. & $18.5^{*}$ & 0.9 & 3.4 \\
\hline Sablefish & 2009 & GOA & 225 & 109 & 4.0 & $16.5^{*}$ & 0.9 & 0.9 \\
\hline Sablefish & 2010 & AI & 13 & 11 & 30.8 & 36.4 & 0.0 & 0.0 \\
\hline Atka mackerel & 2007 & GOA & 23 & 11 & 0.0 & 0.0 & 21.7 & $63.6^{*}$ \\
\hline Atka mackerel & 2009 & GOA & 17 & 15 & 0.0 & 0.0 & 11.8 & 13.3 \\
\hline Atka mackerel & 2010 & $\mathrm{AI}$ & 283 & 107 & 0.0 & 1.9 & 15.9 & 13.1 \\
\hline Walleye pollock & 2007 & GOA & 347 & 442 & 0.0 & 1.8 & 20.2 & 18.3 \\
\hline Walleye pollock & 2009 & GOA & 659 & 359 & 0.0 & 0.3 & $38.8^{*}$ & 11.1 \\
\hline Walleye pollock & 2010 & $\mathrm{AI}$ & 284 & 137 & 0.4 & 1.5 & 27.1 & 24.1 \\
\hline
\end{tabular}

cies that generally feed on small crustaceans, feeding extensively on gelatinous zooplankton (Brodeur et al. 2019b). Similar feeding opportunistically on pelagic tunicates by Argentine anchovy Engraulis anchoita was observed during periods of reduced typical prey concentrations (Mianzan et al. 2001).

The collections analyzed in this study mostly occurred during the summer months (87.9\% of total diet collections were from May to September), as this is the primary period when demersal fishes are surveyed in the study region. However, as shown by Mianzan et al. (1996) and Diaz Briz et al. (2018), incidence of predation on gelatinous zooplankton can be higher for some taxa during other seasons, when alternative crustacean or fish prey may not be as readily available. Due to lower metabolic rates during these cooler seasons, predators may be able to subsist on prey types with lower energy content (Doyle et al. 2007) relative to the summer period. The dominance of summer sampling may have led to an underestimate of the consumption of the larger cnidarians which, by the middle of the summer when most of our survey trawl collections were made, were likely too large to be consumed by most predators examined. In contrast, urochordate feeding peaked in late spring and early summer which may relate to their increased availability during this period, as salps, in particular, form extensive blooms as temperature and zooplankton production increase in higher latitudes during late spring (Henschke et al. 2016, Li et al. 2016).

Most teleosts in northern latitudes lack dentition to tear off parts of larger gelatinous taxa, as some predators in other ecosystems do (e.g. Milisenda et al. 2014), and can only consume whole prey. An excep- tion may be the prowfish, which showed the highest occurrence of gelativory in our sampling, and has likely evolved anatomical adaptions to feeding mainly on scyphozoans (Smith et al. 2014). Additional sampling during the spring and early summer months may reveal the consumption of smaller specimens of the medusae including the ephyra and early juvenile stages. Similarly, many demersal-feeding and scavenger fishes may feed on allochthonous inputs of gelatinous plankton during the late fall and winter following seasonal mass mortality events and jellyfish falls, as observed in other temperate ecosystems (Sweetman et al. 2014, Smith et al. 2016).

Most of our diet data came from stomachs preserved at sea and later analyzed in the laboratory some time after the collections. However, our limited comparison between freshly caught field and laboratory analysis showed that many of these easily digested prey, and especially jellyfish, may be overlooked following extended periods of preservation, due to dissolution of gelatinous tissues during the preservation process. For example, $83.3 \%$ of the SCANS analyses showed occurrences of jellyfish, whereas only $33.3 \%$ of lab analyses showed any jellyfish material. Even fish stomachs that are excised shortly after capture may undergo continued enzymic digestion until the preservative fully penetrates the stomach wall and other prey in the stomach. The rapid digestion and gastric evacuation of gelatinous prey compared to more resistant crustacean and fish prey leads to a negative bias against the importance of gelatinous zooplankton in fish diets (Arai et al. 2003, Hays et al. 2018). Coelenterate predators, such as sablefish, prowfish, and grenadier, caught in trawl nets frequently regurgitate when full of gelatinous 
prey (R. E. Hibpshman pers. obs.). Regurgitation rate in fish increases with sampling depth (Bowman 1986) and these jellyfish feeders are encountered mostly at deeper sampling stations. These factors may lead to high levels of regurgitation of gelatinous prey in deep water fishes. Fish that show signs of regurgitation are discarded and the stomachs are not collected or analyzed, which may contribute to gelatinous prey being underrepresented in the diet data. We suggest that many existing estimates of predation on quickly digested gelatinous forms may be underestimates of the true predation rate, and these rates may need to be adjusted in ecosystem modeling and food consumption studies. Biochemical (stable isotope or fatty acid analysis) or genetic probes may be used to alleviate some of the underreporting of gelatinous tissue in fish predator stomachs (e.g. van der Bank et al. 2011, Cardona et al. 2012, D'Ambra et al. 2015, Lamb et al. 2017, Marques et al. 2019); however, these methods generate binary data and cannot be used to determine magnitude (e.g. percent by number or weight: $\% \mathrm{~N}, \% \mathrm{~W})$. These methods also may not be able to distinguish gelatinous organisms that were secondarily consumed by the main prey, although this potential bias is unlikely for many endotherms (Thiebot \& McInnes 2020).

Although our analysis of $>450000$ non-empty stomachs greatly exceeded similar multispecies studies done previously (e.g. Diaz Briz et al. 2017 analyzed 35200 non-empty stomachs), some predators we included had relatively low sample sizes within a region or year that we suggest may not be as reliable as some of the more numerically abundant species we examined. Optimal sample size for stomach analyses are generally determined as the level at which prey accumulation curves asymptote (Ferry \& Cailliet 1996), although such techniques are used for a diversity of prey items, and are not applicable for a single prey item or a small subset of prey types. In a comprehensive analysis of the diets of groundfish species (snoek Thyrsites atun) in the southern Benguela ecosystem off South Africa, McQueen \& Griffiths (2004) used cumulative prey curves which showed that on average 55 stomachs containing food are required to accurately quantify presence and absence data of a particular prey species. Using this more stringent sample size requirement would have decreased our overall sample size by only 1821 stomachs. However, in doing so, we would have eliminated many potentially important gelativores such as prowfish, searcher, and several rockfish species in some regions (Tables S1-S5) that may not be as abundant or accessible to bottom trawling as some of the other species included with more robust sample sizes. Although including these additional predators in our summary tables provided for a more complete understanding of the utilization of gelatinous prey by fishes, we adopted the criterion of 55 or more samples within a level for all our seasonal and interannual comparisons, which limited our analyses to only 3 taxa satisfying this sample size constraint.

Despite our sampling limitations, this study documented extensive utilization of gelatinous zooplankton by a large number of demersal fishes, including several species with no previous accounts of gelativory. We also showed that many important groundfish species showed little or no utilization of gelatinous prey in all regions examined. Many of these are microcarnivorous or benthophagous species that are not likely to encounter gelatinous zooplankton during the summer months. We caution that although we did not find evidence for feeding on gelatinous zooplankton in these abundant fish species, we cannot say unequivocally that these species do not consume gelatinous taxa, as many of their stomachs were only analyzed in the laboratory. We advocate for additional comparisons between field analyses such as our SCANS method and laboratory analyses post-preservation to verify that these species are not likely gelatinous consumers. If we are confident that a method will detect a gelatinous feeding event, then we can also have increased confidence that absence of detecting it indicates that it did not occur at that time and place, which may improve our conceptualization of the spatial/temporal feeding patterns. These stomach sampling improvements might allow better understanding of the spatial/temporal population dynamics of some of the more common gelatinous prey, which could be important as climate changes and the balance of interspecies dynamics changes. As seen in other ecosystems (Smith et al. 2016, Eriksen et al. 2018, 2020), fish stomach sampling can be utilized as an indicator of increasing gelatinous zooplankton abundance associated with changing ocean conditions.

Identification of trophic guilds that utilize primarily gelatinous zooplankton may be useful for ecosystembased management of LMEs (e.g. Bizzarro et al. 2017). Such results have important implications for energy flow in these systems, and profound effects on food web models presently in use (Pauly et al. 2009, Lamb et al. 2019, Ruzicka et al. 2020). Due to their high growth rates and ability to bloom suddenly and extensively in many systems, the food provisioning role of gelatinous zooplankton in many marine ecosystems should be reappraised (Hamilton 2016, Henschke 
et al. 2016, Hays et al. 2018). There may, as well, be some potential non-energetic benefits (e.g. acquisition of essential compounds or amino acids) of consuming gelatinous taxa to the predator (Thiebot \& McInnes 2020). Although we found few species in the Northeast Pacific that specialize on gelatinous taxa, the large number of species facultatively feeding on these prey indicate that they likely play an important, unappreciated role in the food web, as shown in other areas (Mianzan et al. 1996, Arkhipkin \& Laptikhovsky 2013, Smith et al. 2016, Diaz Briz et al. 2017), and therefore should no longer be considered 'trophic dead ends'. Moreover, despite the relative low overall percentages of gelatinous taxa in the diets of some of the more abundant predators (i.e. walleye pollock, sablefish, Atka mackerel, some flatfishes), the relatively high biomasses of these species in the Northeast Pacific have the potential to impact jellyfish standing stocks in years when high predation rates occur.

Acknowledgements. The authors sincerely thank the AFSC and the NWFSC groundfish bottom trawl survey teams and volunteers for their outstanding efforts to collect so many stomach samples at sea over the many years. We also appreciate the work of the many staff and students that examined the stomachs in the laboratory. We thank Drs. Aimee Keller, Joseph Bizzarro, Tom Doyle, and 2 anonymous reviewers for thoughtful suggestions which improved the manuscript. Funding for this work has been provided by NOAA's Northwest and Alaska Fisheries Science Centers.

\section{LITERATURE CITED}

Adams PB (1987) The diet of widow rockfish Sebastes entomelas in Northern California. NOAA Tech Rep NMFS 48:37-41

Arai MN (1988) Interactions of fish and pelagic coelenterates. Can J Zool 66:1913-1927

Arai MN (2005) Predation on pelagic coelenterates: a review. J Mar Biol Assoc UK 85:523-536

Arai MN, Welch DW, Dunsmuir AL, Jacobs MC, Ladouceur AR (2003) Digestion of pelagic Ctenophora and Cnidaria by fish. Can J Fish Aquat Sci 60:825-829

Archer SK, Kahn AS, Leys SP, Norgard T, Girard F, Du Preez C, Dunham A (2018) Pyrosome consumption by benthic organisms during blooms in the NE Pacific and Gulf of Mexico. Ecology 99:981-984

Arkhipkin A, Laptikhovsky V (2013) From gelatinous to muscle food chain: rock cod Patagonotothen ramsayi recycles coelenterate and tunicate resources on the Patagonian Shelf. J Fish Biol 83:1210-1220

Ates RML (2017) Benthic scavengers and predators of jellyfish, material for a review. Plankton Benthos Res 12: 71-77

* Bizzarro JJ, Yoklavich MM, Wakefield WW (2017) Diet composition and foraging ecology of US Pacific Coast groundfishes with applications for fisheries management. Environ Biol Fishes 100:375-393

Bowman RE (1986) Effect of regurgitation on stomach content data of marine fishes. Environ Biol Fishes 16:171-181
Brodeur RD, Pearcy WG (1992) Effects of environmental variability on trophic interactions and food web structure in a pelagic upwelling ecosystem. Mar Ecol Prog Ser 84: 101-119

Brodeur RD, Daly EA, Sturdevant MV, Miller TW and others (2007) Regional comparisons of juvenile salmon feeding in coastal marine waters off the west coast of North America. Am Fish Soc Symp 57:183-203

Brodeur RD, Decker MB, Ciannelli L, Purcell JE and others (2008) Rise and fall of jellyfish in the eastern Bering Sea in relation to climate regime shifts. Prog Oceanogr 77: 103-111

Brodeur R, Perry I, Boldt J, Flostrand L and others (2017) An unusual gelatinous plankton event in the NE Pacific: the great pyrosome bloom of 2017. PICES Press 26:22-27

*Borodeur RD, Hunsicker ME, Hann A, Miller TW (2019a) Effects of warming ocean conditions on feeding ecology of small pelagic fishes in a coastal upwelling ecosystem: a shift to gelatinous food sources. Mar Ecol Prog Ser 617618:149-163

*Bodeur RD, Auth TD, Phillips AJ (2019b) Major shifts in macroplankton and micronekton pelagic community structure in an upwelling ecosystem related to an unprecedented marine heatwave. Front Mar Sci 6:212

*Botz L, Cheung WWL, Kleisner K, Pakhomov E, Pauly D (2012) Increasing jellyfish populations: trends in Large Marine Ecosystems. Hydrobiologia 690:3-20

Buckley TW, Tyler GE, Smith DM, Livingston PA (1999) Food habits of some commercially important groundfish off the coasts of California, Oregon, Washington, and British Columbia. NOAA Tech Memo NMFS-AFSC-102

Cardona L, De Quevedo IÁ, Borrell A, Aguilar A (2012) Massive consumption of gelatinous plankton by Mediterranean apex predators. PLOS ONE 7:e31329

* Condon RH, Duarte CM, Pitt KA, Robinson KL and others (2013) Recurrent jellyfish blooms are a consequence of global oscillations. Proc Natl Acad Sci USA 110: 1000-1005

“D'Ambra I, Graham WM, Carmichael RH, Hernandez FJ Jr (2015) Fish rely on scyphozoan hosts as primary food source: evidence from stable isotope analysis. Mar Biol 162:247-252

Diaz Briz L, Sánchez F, Marí N, Mianzan H, Genzano G (2017) Gelatinous zooplankton (ctenophores, salps and medusae): an important food resource of fishes in the temperate SW Atlantic Ocean. Mar Biol Res 13:630-644

Diaz Briz L, Sánchez F, Marí N, Genzano G (2018) Seasonal variation of gelatinous plankton consumption by fish in the south-western Atlantic Ocean: a question of strategy. Mar Biol Res 14:739-751

* Doyle TK, Houghton JDR, McDevitt R, Davenport J, Hays GC (2007) The energy density of jellyfish: estimates from bomb-calorimetry and proximate-consumption. J Exp Mar Biol Ecol 343:239-252

KEriksen E, Bogstad B, Dolgov A, Beck IM (2018) Cod diet as an indicator of Ctenophora abundance dynamics in the Barents Sea. Mar Ecol Prog Ser 591:87-100

* Eriksen E, Benzik AN, Dolgov AV, Skjoldal HR and others (2020) Diet and trophic structure of fishes in the Barents Sea: the Norwegian-Russian program "Year of stomachs" 2015-establishing a baseline. Prog Oceanogr 183: 102262

Ferry LA, Cailliet GM (1996) Sample size and data analysis: Are we characterising and comparing diet properly? In: MacKinlay D, Shearer K (eds) Gutshop '96: feeding ecol- 
ogy and nutrition in fish: symposium proceedings. American Fisheries Society, San Francisco, CA, p 71-80

Hamilton G (2016) The secret lives of jellyfish. Nature 531: 432-434

Hays GC, Doyle TK, Houghton JDR (2018) A paradigm shift in the trophic importance of jellyfish? Trends Ecol Evol 33:874-884

Henschke N, Everett JD, Richardson AJ, Suthers IM (2016) Rethinking the role of salps in the ocean. Trends Ecol Evol 31:720-733

Hobson ES, Chess JR (1988) Trophic relations of the blue rockfish, Sebastes mystinus, in a coastal upwelling system off Northern California. Fish Bull 86:715-743

Hobson ES, Chess JR, Howard DF (1996) Zooplankters consumed by blue rockfish during brief access to a current off California's Sonoma Coast. Calif Fish Game 82:87-92

Kashkina AA (1986) Feeding of fishes on salps (Tunicata, Thaliacea). J Ichthyol 26:57-64

Keller AA, Wallace JR, Methot RD (2017) The Northwest Fisheries Science Center's west coast groundfish bottom trawl survey: history, design, and description. NOAA Tech Memo NMFS-NWFSC-136

Laidig TE, Adams PB, Samiere WM (1997) Feeding habits of sablefish, Anoplopoma fimbria, off the coast of Oregon and California. NOAA Tech Rep 130:65-79

Lamb PD, Hunter E, Pinnegar JK, Creer S, Davies RG, Taylor MI (2017) Jellyfish on the menu: mtDNA assay reveals scyphozoan predation in the Irish Sea. R Soc Open Sci 4:171421

Lamb PD, Hunter E, Pinnegar JK, Doyle TK, Creer S, Taylor MI (2019) Inclusion of jellyfish in 30+ years of Ecopath with Ecosim models. ICES J Mar Sci 76:1941-1950

Lee YH, Sampson DB (2009) Dietary variations in three cooccurring rockfish species off the Pacific Northwest during anomalous oceanographic conditions in 1998 and 1999. Fish Bull 107:510-522

* Li K, Doubleday AJ, Galbraith MD, Hopcroft RR (2016) High abundance of salps in the coastal Gulf of Alaska during 2011: a first record of bloom occurrence for the northern Gulf. Deep Sea Res II 132:136-145

KLivingston PA, Aydin K, Buckley TW, Lang GM, Yang MS, Miller BS (2017) Quantifying food web interactions in the North Pacific - a data-based approach. Environ Biol Fishes 100:443-470

*ucas CH, Dawson MN (2014) What are jellyfishes and thaliaceans and why do they bloom? In: Pitt KA, Lucas $\mathrm{CH}$ (eds) Jellyfish blooms. Springer, Dordrecht, p 9-42

Marques R, Darnaude AM, Crochemore S, Bouvier C, Bonnet D (2019) Molecular approach indicates consumption of jellyfishes by commercially important fish species in a coastal Mediterranean lagoon. Mar Env Res 152:104787

McQueen N, Griffiths MH (2004) Influence of sample size and sampling frequency on the quantitative dietary descriptions of a predatory fish in the Benguela ecosystem. Afr J Mar Sci 26:205-217

Mianzan HW, Mari N, Prenski B, Sanchez F (1996) Fish predation on neritic ctenophores from the Argentine continental shelf: a neglected food resource? Fish Res 27: 69-79

Editorial responsibility: André C. Morandini (Guest Editor),

São Paulo, Brazil

Reviewers: 3 anonymous referees
Mianzan HW, Pájaro M, Álvarez Colombo GL, Madirolas A (2001) Feeding on survival-food: gelatinous plankton as a source of food for anchovies. Hydrobiologia 451:45-53

Milisenda G, Rosa S, Fuentes VL, Boero F, Guglielmo L, Purcell JE, Piraino S (2014) Jellyfish as prey: frequency of predation and selective foraging of Boops boops (Vertebrata, Actinopterygii) on the mauve stinger Pelagia noctiluca (Cnidaria, Scyphozoa). PLOS ONE 9:e94600

Miller RR, Santora JA, Auth TD, Sakuma KM, Wells BK, Field JC, Brodeur RD (2019) Distribution of pelagic thaliaceans, Thetys vagina and Pyrosoma atlanticum, during a period of mass occurrence within the California Current Large Marine Ecosystem. CCOFI Rep 60:108-122

Opdal AF, Brodeur RD, Cieciel K, Daskalov GM and others (2019) Unclear associations between pelagic fish and jellyfish in several major marine ecosystems. Sci Rep 9: 2997

*Pauly D, Graham W, Libralato S, Morissette L, Palomares MD (2009) Jellyfish in ecosystems, online databases, and ecosystem models. Hydrobiologia 616:67-85

Purcell JE, Arai MN (2001) Interactions of pelagic cnidarians and ctenophores with fish: a review. Hydrobiologia 451: $27-44$

Richardson AJ, Bakun A, Hays GC, Gibbons MJ (2009) The jellyfish joyride: causes, consequences and management responses to a more gelatinous future. Trends Ecol Evol 24:312-322

* Ruzicka JJ, Brodeur RD, Emmett RL, Steele JH and others (2012) Interannual variability in the Northern California Current food web structure: changes in energy flow pathways and the role of forage fish, euphausiids, and jellyfish. Prog Oceanogr 102:19-41

* Ruzicka J, Brodeur RD, Cieciel K, Decker MB (2020) Examining the ecological role of jellyfish in the Eastern Bering Sea ecosystem. ICES J Mar Sci 77:791-802

Smith KR, Somerton DA, Yang MS, Nichol DG (2014) Distribution and biology of prowfish (Zaprora silenus) in the northeast Pacific. Fish Bull 102:168-178

* Smith BE, Ford MD, Link JS (2016) Bloom or bust: synchrony in jellyfish abundance, fish consumption, benthic scavenger abundance, and environmental drivers across a continental shelf. Fish Oceanogr 25:500-514

* Sweetman AK, Smith CR, Dale T, Jones DOB (2014) Rapid scavenging of jellyfish carcasses reveals the importance of gelatinous material to deep-sea food webs. Proc R Soc B 281:20142210

* Thiebot JB, McInnes JC (2020) Why do marine endotherms eat gelatinous prey? ICES J Mar Sci 77:58-71

Uye SI, Brodeur RD (2017) Jellyfish blooms around the North Pacific Rim: causes and consequences. PICES Scientific Report No. 51. North Pacific Marine Science Organization, Sidney

* van der Bank MG, Utne-Palm AC, Pittman K, Sweetman AK, Richoux NB, Brüchert V, Gibbons MJ (2011) Dietary success of a 'new' key fish in an overfished ecosystem: evidence from fatty acid and stable isotope signatures. Mar Ecol Prog Ser 428:219-233

Zar JH (1984) Biostatistical analysis, $2^{\text {nd }}$ edn. Prentice-Hall, Englewood Cliffs, NJ

Submitted: May 12, 2020

Accepted: September 4, 2020

Proofs received from author(s): November 20, 2020 